\title{
Safety of Microstream Capnography Monitoring in Patients Under Sedation for Colonoscopy
}

\section{Sedasyon Altında Kolonoskopi Uygulanan Hastalarda Mikrostream Kapnograf Monitörizasyonunun Güvenilirliği}

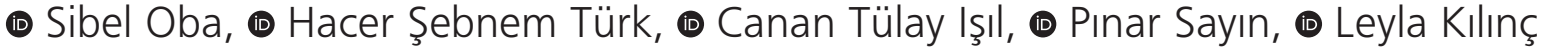 \\ Şişli Hamidiye Etfal Training and Research Hospital, Clinic of Anesteziyoloji ve Reanimasyon, Istanbul, Turkey
}

Abstract

Aim: The purpose of this study was to investigate the effectiveness of micro stream capnography in early recognition of adverse events during sedation for colonoscopy.

Methods: This prospective randomized study was performed implemented on 82 adults scheduled for elective colonoscopy. $\mathrm{SpO}_{2}, \mathrm{ETCO}_{2}$ and integrated pulmonary index (IPI) values were measured with the use of micro stream capnography and recorded. Arterial blood gas samples were taken at the beginning, 10th minute and end of the procedure and analyzed.

Results: The correlation between mean values of IPI and mean values of $\mathrm{ETCO}_{2}, \mathrm{SpO}_{2}$ and $\mathrm{PaCO}_{2}$ was not statistically significant. There was a statistically significant correlation between IPI value at the beginning and $\mathrm{PaCO}_{2}$ value at the end of the procedure. Correlation of IPI value at the 10th minute with $\mathrm{SpO}_{2}$ at the $10^{\text {th }}$ minute and $\mathrm{SPO}_{2}$ value at the end of the procedure was statistically significant.

Conclusion: Non-invasive $\mathrm{ETCO}_{2}$ monitoring with micro stream capnography is correlated with $\mathrm{PaCO}_{2}$ values in arterial blood gas analysis, which is useful for monitoring of sedation and hypoventilation during colonoscopy procedures. However, IPI monitoring is not of clinical benefit to early recognition of hypoventilation. Non-invasive $\mathrm{ETCO}_{2}$ monitoring with micro stream capnography should be a part of routine monitoring for safe anesthetic practice outside the operating room.

Keywords: Capnography, EndCO 2 IPI, micro stream, $\mathrm{PaCO}_{2}$
Öz

Amaç: Bu çalışmanın amacı, kolonoskopi için uygulanan sedasyon sırasında advers olayların erken tanısı için mikrostream kapnografinin etkinliğini araştırmaktır.

Yöntemler: Bu prospektif randomize çalışma, elektif kolonoskopi planlanan 82 yetişkin üzerinde gerçekleştirildi. $\mathrm{SpO}_{2}, \mathrm{EndCO}_{2}$ ve IPI değerleri mikrostream monitör ile ölçüldü ve kaydedildi. Başlangıç, 10. dakika ve işlem sonu arteriyel kan gazı örneği alındı ve analiz edildi.

Bulgular: Entegre pulmoner indeks (IPI) ortalama değerleri ile EndCO $\mathrm{CO}_{2}, \mathrm{SpO}_{2}$ ve $\mathrm{PaCO}_{2}$ ortalama değerleri arasında istatistiksel olarak anlamlı korelasyon bulunmadı. IPI başlangıç değeri ile $\mathrm{PaCO}_{2}$ prosedür sonu değeri arasında istatistiksel olarak anlamlı bir ilişki saptandı; IPI 10. dakika değerinin, $\mathrm{SpO}_{2}$ 10. dakika ve $\mathrm{SpO}_{2}$ prosedür sonu değerleriyle karşılaştırılması istatiksel olarak anlamlı bulundu.

Sonuç: Kolonoskopik prosedürler sırasında sedasyon ve hipoventilasyonun izlenmesi için, mikrostream kapnografı ile non-invazif $\mathrm{EndCO}_{2}$ takibi, arteriyel kan gazı örneklerindeki $\mathrm{PaCO}_{2}$ değerleri ile uyumludur. Ancak IPI monitorizasyonu, hipoventilasyonun erken tanınmasında klinik yarar sağlamaz. Operasyon odası dışında güvenli anestezi uygulaması için mikrostream kapnograf ile non-invazif $\mathrm{EndCO}_{2}$ monitorizasyonu rutin izlemenin bir parçası olmalıdır.

Anahtar Sözcükler: Kapnograf, EndCO, IPI, mikro stream, $\mathrm{PaCO}_{2}$
Address for Correspondence/Yazışma Adresi: Hacer Şebnem Türk, Şişli Hamidiye Etfal Training and Research Hospital, Clinic of Anesteziyoloji ve Reanimasyon, İstanbul, Turkey Phone: +90 5324432544 E-mail: hacersebnem@yahoo.com.tr ORCID: orcid.org/0000-0003-0225-1965 Received/Geliş Tarihi: 10 October 2018 Accepted/Kabul Tarihi: 03 December 2018

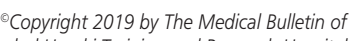
istanbul Haseki Training and Research Hospital The Medical Bulletin of Haseki published by Galenos Yayınevi. ${ }^{-}$Telif Hakkı 2019 İstanbul Haseki Eğitim ve Araştırma Hastanesi Haseki Tip Bülteni, Galenos Yayınevi tarafindan yayınlanmıştır. 


\section{Introduction}

Recently, sedation for colonoscopy has become a frequent anesthetic practice. Possible hypoxic episodes due to sedation are monitored with pulse-oxymeter saturation $\left(\mathrm{SpO}_{2}\right)$ and respiratory depression or apnea is detected with $\mathrm{SpO}_{2}$ measurement. However, the quality of ventilation monitoring is not satisfactory in patients receiving sedation (1). Carbon dioxide $\left(\mathrm{CO}_{2}\right)$ measurements, which can be analysed via arterial blood gas sampling correctly, are the best method to assess alveolar ventilation. However, it is difficult to take several arterial blood samples and biochemically analyse them during a short procedure such as colonoscopy. Therefore, the end-tidal carbon dioxide $\left(\mathrm{ETCO}_{2}\right)$ monitoring has become the favorite method of carbon dioxide monitoring. It is a continuous and noninvasive method of measuring $\mathrm{CO}_{2}$. Capnographs are indispensable for expiratory carbon dioxide measurements in the operation theaters. However, these monitors can measure $\mathrm{ETCO}_{2}$ only in intubated patients. Thus, various devices have been developed for monitoring $\mathrm{ETCO}_{2}$ noninvasively in spontaneously breathing patients $(2,3)$.

Micro stream capnograph is a medical device providing continuous monitoring of $\mathrm{ETCO}_{2}$ non-invasively through a nasal sampling line at the patient's bedside $(4,5)$. Micro stream monitor can also assess the Integrated Pulmonary Index (IPI) value which is a mathematically determined factor based on parameters of capnography $\left(\mathrm{ETCO}_{2}\right.$, respiratory rate) and pulse oximetry (pulse rate and $\mathrm{SpO}_{2}$ ). Previously, reliability of this device was studied in critically ill patients with spontaneous breathing, and non-invasive $\mathrm{ETCO}_{2}$ was found to be correlated with arterial blood gas analyses $(6,7)$.

Patients presenting for gastrointestinal endoscopy under sedation may have a high-risk profile and despite many studies to increase the safety of endoscopic procedures, mortality and morbidity associated with cardiopulmonary complications during endoscopic procedures remain a challenge.

In this study, we aimed to investigate the efficacy of micro stream capnography for early recognition of adverse events in patients under sedation for colonoscopy. We assessed the correlation between non-invasive $\mathrm{ETCO}_{2}$ measurement and arterial blood gas analyses and the correlation of IPI with $\mathrm{ETCO}_{2}, \mathrm{SPO}_{2}$ and $\mathrm{PaCO}_{2}$.

\section{Methods}

After obtaining approval from the Local Ethics Committee of Şisli Etfal Training and Research Hospital (03.03.2015/883) and verbal and written informed consent from all patients, this prospective randomized study was performed in the gastrointestinal endoscopy unit at our hospital between March and September 2015.
A total of 100 adults aged $>18$ years, graded as American Society of Anesthesiologists physical status (ASA) I-III, and scheduled for elective colonoscopy were included in the study. Those, who did not want to participate, children, pregnant women, patients with severe cardiac or respiratory insufficiency, neuropsychiatric disorders, alcohol or drug addiction, allergy to anesthetics, peripheral vascular diseases or airway deformities, were excluded from the study.

All patients were inserted an 18-gauge intravenous catheter. No premedication was used. In the procedure room, the patient was placed in the lateral decubitus position. Standard monitoring with electrocardiography, non-invasive systemic blood pressure and pulse oxymeter $\left(\mathrm{SPO}_{2}\right)$ was done and heart rate $(\mathrm{HR})$, mean arterial blood pressure (MABP) and $\mathrm{SPO}_{2}$ values at the baseline were recorded. A nasal sample line (Nasal FilterLine ${ }^{\mathrm{TM}}$, Covidien, Colorado, USA) was placed; $\mathrm{ETCO}_{2}$ and respiratory rate (RR) and IPI were measured and recorded with a microstream monitor (CapnoStream ${ }^{\mathrm{TM}}$, Covidien, Colorado, U.S.A.). Bispectral Index (BIS) monitoring (BIS monitor ${ }^{\mathrm{TM}}$, Covidien, Colorado, U.S.A.) was also performed and baseline value was recorded.

All patients received standard anesthetic induction with $1 \mu \mathrm{g} \cdot \mathrm{kg}^{-1}$ fentanyl (Talinat ${ }^{\circledR} 0.5 \mathrm{mg} / 10 \mathrm{~mL}$ ampule, VEM, istanbul, Turkey) and 1.0 mg.kg-1 propofol (Propofol ${ }^{\circledR} 1 \% 10 \mathrm{~mL}$ ampule, Fresenius, Uppsala, Sweden). During the procedure, all patients were given additional $0.5 \mathrm{mg} \cdot \mathrm{kg}^{-1}$ dose of propofol, when necessary, to maintain the Ramsey Sedation Score (RSS) between 3 and 4.

Immediately after sedation a radial arterial cannula was inserted. Beginning arterial blood gas sample was taken and analysed at the beginning of the procedure. Two more samples were taken at the $10^{\text {th }}$ minute and at the end of the procedure. $\mathrm{pH}, \mathrm{PaO}_{2}, \mathrm{PaCO}_{2}, \mathrm{SO}_{2}$, $\mathrm{HCO}_{3}$ and base excess values were recorded. $\mathrm{HR}$, $\mathrm{MABP}, \mathrm{SPO}_{2}, \mathrm{RSS}, \mathrm{BIS}, \mathrm{ETCO}{ }_{2}$, IPI and RR were recorded synchronously with arterial blood gas samplings. The correlation of IPI values with patient status are shown in Table 1.

\begin{tabular}{|c|c|}
\hline 10 & Normal \\
\hline $8-9$ & Within normal range \\
\hline 7 & $\begin{array}{l}\text { Close to normal range; requires } \\
\text { attention }\end{array}$ \\
\hline $5-6$ & $\begin{array}{l}\text { Requires attention and may require } \\
\text { intervention }\end{array}$ \\
\hline $3-4$ & Requires intervention \\
\hline $1-2$ & Requires immediate intervention \\
\hline
\end{tabular}


Oxygen insufflation was done with oxygen flowing at $2 \mathrm{~L} / \mathrm{min}$ via nasal prongs in patients with a $\mathrm{SPO}_{2}<90 \%$ and these patients were recorded.

Anesthesia time was the time from anesthetic induction to recovery. Endoscopy time was defined as the time from endoscopy start to endoscopy completion. Recovery time was the time from the end of endoscopy until patient's recovery to RSS 2.

Patients who achieved an Aldrete score of 9 were discharged.

The total propofol dose was calculated and recorded. Allergic reactions, which were observed during the procedure, bradycardia ( $\mathrm{HR}<50$ beats per min), tachycardia (20\% increase in HR), hypotension (MABP $<60 \mathrm{mmHg}$ ), hypertension (20\% increase in MABP), respiratory depression, desaturation $\left(\mathrm{SPO}_{2}<90 \%\right)$, hypoventilation (>20\% reduction in $\mathrm{ETCO}_{2}$ compared with baseline value), nausea, vomiting, hemorrhage and perforation were recorded.

\section{Results}

A total of 82 patients were included in this study. Fail arterial cannulation, clotted blood sample and discontinuation of colonoscopy due to inadequate colon cleansing were the reasons for exclusion of 18 patients.

The male-to-female ratio was 42/40; 34 patients were graded as ASA I, 36 patients - ASA II and 12 patients - ASA III. Demographic characteristics of the patients are shown in Table 2.

Variations in $\mathrm{HR}, \mathrm{SpO}_{2}, \mathrm{MABP}$ and $\mathrm{ETCO}_{2}$ at three times analysis were statistically significant $(p<0.001)$. $\mathrm{ETCO}_{2}$ measurements at the $10^{\text {th }}$ minute and end of the procedure were statistically significantly higher compared to that at the beginning of the procedure $(p=0.002)$ $(p=0.005)$. There was no statistically significant difference between $\mathrm{ETCO}_{2}$ measurements at the $10^{\text {th }}$ minute and end of the procedure $(p=0.416)$. IPI values at the beginning, $10^{\text {th }}$ minute and at the end of the procedure were not statistically different $(p=0.152)$.

Bispectral index (BIS) value was statistically significantly decreased at the $10^{\text {th }}$ minute

\begin{tabular}{|l|l|l|}
\hline \multicolumn{2}{|l|}{ Table 2. Demographical data } \\
\hline & Minimum-Maximum & Mean \pm SD \\
\hline Age (years) & $23-86$ & $51.04 \pm 12.42$ \\
\hline Weight (kg) & $50-100$ & $71.78 \pm 11.19$ \\
\hline Anesthesia duration (min) & $14-30$ & $20.82 \pm 4.35$ \\
\hline Endoscopy duration (min) & $13-27$ & $19.3 \pm 4.51$ \\
\hline Recovery period (min) & $2-6$ & $3.56 \pm 1.11$ \\
\hline Propofol consumption (mg) & $70-240$ & $107.01 \pm 33.51$ \\
\hline SD: Standard deviation, min: Minute \\
\hline
\end{tabular}

and end of the procedure compared to that at the beginning of the procedure $(p<0.001)$ (Table 3).

RSS scores were statistically significantly different than the baseline values $(p<0.001)$. There was no statistically significant difference between baseline and $10^{\text {th }}$ minute RSS scores and between RSS scores at the $10^{\text {th }}$ minute and end of the procedure. There was a statistically significant difference between baseline RSS score and that at the end of the procedure $(p=0.001)$.

Correlations in $\mathrm{pH}, \mathrm{PaO}_{2}, \mathrm{PaCO}_{2}, \mathrm{HCO}_{3}$ and $\mathrm{SpO}_{2}$ were statistically significant (Table 4).

No statistically significant difference was determined in $\mathrm{PaCO}_{2}$ and $\mathrm{ETCO}_{2}$ between all measurements (Table 5).

The correlation between the mean IPI value and the mean $\mathrm{ETCO}_{2}, \mathrm{SpO}_{2}$ and $\mathrm{PaCO}_{2}$ values was not statistically significant (Table 6).

There was a statistically significant correlation between baseline IPI value and $\mathrm{PaCO}_{2}$ value at the end of the procedure; IPI value at the $10^{\text {th }}$ minute and $\mathrm{SpO}_{2}$ value at the $10^{\text {th }}$ minute; IPI value at the $10^{\text {th }}$ minute and $\mathrm{SPO}_{2}$ value at the end of the procedure (Table 7 ).

Desaturation was observed in three patients and treated with oxygen supplement. Hypotension was observed in nine patients; five patients received fluid and ephedrine intravenously and four patients received fluid replacement. Bradycardia was observed in the presence of hypotension. $\mathrm{ETCO}_{2}$ measurement revealed hypoventilation in nine patients while IPI levels under 7 were recorded in four patients. Arterial blood gas $\mathrm{PaCO}_{2}$ showed hypoventilation in 13 patients. Complication associated with the procedure was not observed in any patient.

\section{Statistical Analysis}

For statistical analysis, NCSS (Number Cruncher Statistical System) 2007 (Kaysville, Utah, USA) program was used. Study data was evaluated with descriptive statistical methods (mean, standard deviation, median, frequency, percentage minimum, maximum). Quantitative data in normal distribution was compared with the repeated measures ANOVA. Correlation between the variables was evaluated with Pearson's correlation coefficient. A p value of less than 0.01 or 0.05 was considered statistically significant.

\section{Discussion}

Recently $\mathrm{ETCO}_{2}$ measuring has become a part of routine monitoring and capnographs are commonly used in operation theaters and intensive care units (7-9). Capnographic monitoring also prevents redundant blood gas analyses, thus reduces unnecessary costs (9). 


\begin{tabular}{|c|c|c|c|}
\hline Heart Rate & $\begin{array}{l}\text { Minimum/ } \\
\text { Maximum }\end{array}$ & Mean \pm SD & ap \\
\hline Beginning & $53 / 123$ & $85.87 \pm 12.36$ & \multirow[t]{3}{*}{$<0.001^{* *}$} \\
\hline $10^{\text {th }}$ minute & $55 / 109$ & $77.90 \pm 9.41$ & \\
\hline End & $54 / 111$ & $78.28 \pm 9.69$ & \\
\hline \multicolumn{3}{|l|}{ Difference } & ${ }^{b} p$ \\
\hline Beginning-10th minute & $-47 / 27$ & $-7.97 \pm 11.49$ & $<0.001^{* *}$ \\
\hline Beginning-end & $-46 / 29$ & $-7.59 \pm 11.28$ & $<0.001^{* *}$ \\
\hline $10^{\text {th }}$ minute-end & $-15 / 25$ & $-0.38 \pm 5.28$ & 0.525 \\
\hline $\mathrm{SPO}_{2}$ & $\begin{array}{l}\text { Minimum/ } \\
\text { Maximum }\end{array}$ & Mean \pm SD & ap \\
\hline Beginning & $93 / 100$ & $98.01 \pm 1.64$ & \multirow[t]{3}{*}{$<0.001^{* *}$} \\
\hline $10^{\text {th }}$ minute & $87 / 100$ & $94.24 \pm 2.16$ & \\
\hline End & $90 / 100$ & $95.19 \pm 2.00$ & \\
\hline \multicolumn{3}{|l|}{ Difference } & ${ }^{b} p$ \\
\hline Beginning- $10^{\text {th }}$ minute & $-13 / 2$ & $-3.77 \pm 2.55$ & $<0.001$ ** \\
\hline Beginning-end & $-9 / 2$ & $-2.82 \pm 2.24$ & $<0.001^{* *}$ \\
\hline $10^{\text {th }}$ minute-end & $-9 / 3$ & $-0.94 \pm 1.65$ & $<0.001^{* *}$ \\
\hline MABP & $\begin{array}{l}\text { Minimum/ } \\
\text { Maximum }\end{array}$ & Mean \pm SD & ${ }^{a p}$ \\
\hline Beginning & $51 / 134$ & $86.44 \pm 15.65$ & \multirow[t]{3}{*}{$<0.001^{* *}$} \\
\hline 10th minute & $50 / 138$ & $77.90 \pm 14.18$ & \\
\hline End & $46 / 167$ & $78.89 \pm 16.42$ & \\
\hline \multicolumn{3}{|l|}{ Difference } & ${ }^{b} p$ \\
\hline Beginning-10th minute & $-59 / 18$ & $-8.54 \pm 13.47$ & $<0.001$ ** \\
\hline Beginning-end & $-53 / 43$ & $-7.56 \pm 15.59$ & $<0.001^{* *}$ \\
\hline $10^{\text {th }}$ minute-end & $-34 / 39$ & $-0.98 \pm 11.36$ & 0.442 \\
\hline END $\mathrm{CO}_{2}$ & $\begin{array}{l}\text { Minimum/ } \\
\text { Maximum }\end{array}$ & Mean \pm SD & ap \\
\hline Beginning & $26 / 44$ & $36.11 \pm 3.25$ & \multirow[t]{3}{*}{$0.001 * *$} \\
\hline $10^{\text {th }}$ minute & $30 / 50$ & $37.62 \pm 3.83$ & \\
\hline End & $29 / 50$ & $37.32 \pm 3.51$ & \\
\hline \multicolumn{3}{|l|}{ Difference } & ${ }^{b} p$ \\
\hline Beginning-10th minute & $-12 / 11$ & $1.51 \pm 4.21$ & $0.002^{* *}$ \\
\hline Beginning-end & $-8 / 13$ & $1.20 \pm 3.66$ & $0.005^{* *}$ \\
\hline $10^{\text {th }}$ minute-end & $-9 / 12$ & $0.30 \pm 3.29$ & 0.416 \\
\hline IPI & $\begin{array}{l}\text { Minimum/ } \\
\text { Maximum }\end{array}$ & Mean \pm SD & ap \\
\hline Beginning & $6 / 10$ & $9.33 \pm 0.97$ & \multirow[t]{3}{*}{0.152} \\
\hline $10^{\text {th }}$ minute & $4 / 10$ & $9.03 \pm 1.27$ & \\
\hline End & $5 / 10$ & $9.00 \pm 1.24$ & \\
\hline BIS & $\begin{array}{l}\text { Minimum/ } \\
\text { Maximum }\end{array}$ & Mean \pm SD & ap \\
\hline Beginning & $96 / 100$ & $98.49 \pm 1.14$ & \multirow[t]{3}{*}{$<0.001^{* x}$} \\
\hline $10^{\text {th }}$ minute & $46 / 77$ & $60.70 \pm 6.44$ & \\
\hline End & $49 / 88$ & $67.82 \pm 5.99$ & \\
\hline
\end{tabular}

\begin{tabular}{|c|c|c|c|}
\hline \multicolumn{3}{|l|}{ Difference } & \multirow{2}{*}{$\begin{array}{l}\mathbf{b}_{\mathbf{p}} \\
<0.001^{* *}\end{array}$} \\
\hline Beginning-10th minute & $-53 /-21$ & $-37.80 \pm 6.37$ & \\
\hline Beginning-end & $-50 /-12$ & $-30.67 \pm 5.98$ & $<0.001 * *$ \\
\hline $10^{\text {th }}$ minute-end & $-33 / 7$ & $-7.13 \pm 6.12$ & $<0.001^{* *}$ \\
\hline \multicolumn{4}{|c|}{$\begin{array}{l}\text { SD: Standard deviation, } \mathrm{SPO}_{2} \text { : Saturation, MABP: Mean arterial blood pressure, } \\
\text { End } \mathrm{CO}_{2} \text { : End tidal carbondioxide, IPI: Integrated pulmonary index, BIS: Bispectra } \\
\text { index } \\
p<0.05 \text { is statistically meaningful; aRepeated Measures ANOVA, bPaired samples } \\
\text { t test }\end{array}$} \\
\hline
\end{tabular}

Non-invasive devices have been developed to monitor $\mathrm{ETCO}_{2}$ values in spontaneously breathing patients. These are usually used in intensive care units to monitor $\mathrm{ETCO}_{2}$ in patients receiving non-invasive mechanical ventilation (10-12). One of them is micro stream capnography, which measures $\mathrm{ETCO}_{2}$ and IPI values through a nasal cannula (6).

Sedation is given in the endoscopy units for gastroscopy and colonoscopy procedures and patient's recovery is usually monitored with $\mathrm{SpO}_{2}$ (8). ETCO ${ }_{2}$, which is the most important value in assessing ventilation, is not monitored routinely during sedation. Most recent guidelines do not recommend a routine use of capnography during endoscopic sedation (6). Anesthesia outside the operating room is difficult to practice. To make anesthetic procedures safer, some questions need to be answered: Should $\mathrm{ETCO}_{2}$ routinely be monitored? To what degree are the measurements correlated with arterial blood gas analyses? Is IPI value is predictive of hypoventilation? In this study, the answers to these questions were investigated on patients monitored with micro stream capnograph during colonoscopy.

Arterial blood gas analyses in endoscopic procedures with or without sedation to evaluate oxygenation and ventilation showed no variations in $\mathrm{PaCO}_{2}$ values in patients under sedation, but a decrease in $\mathrm{PaO}_{2}$ values. This decrease was of short duration and recovered to the baseline value. In the literature all studies were conducted in upper gastrointestinal system endoscopy and under benzodiazepine sedation (13-15). However, propofol is commonly used for sedation in colonoscopy procedures today. However, propofol has respiratory depressant effects (16).

Despite increasing efforts to increase the safety of endoscopic procedures, mortality and morbidity associated with cardiopulmonary complications during endoscopic procedures remain a challenge. In this study, we measured $\mathrm{ETCO}_{2}$ and IPI values with micro stream capnography, which has advanced technology and works even with very low tidal volumes such as $50 \mathrm{~mL}$ without trapping moisture and water. We aimed to investigate the safety of endoscopic procedures monitored by micro stream capnography. 


\begin{tabular}{|c|c|c|c|}
\hline $\mathrm{Ph}$ & $\begin{array}{l}\text { Minimum/ } \\
\text { Maximum }\end{array}$ & Mean \pm SD & ap \\
\hline Beginning & $7.31 / 7.43$ & $7.36 \pm 0.02$ & \multirow{3}{*}{$0.018^{*}$} \\
\hline $10^{\text {th }}$ minute & 7. $30 / 7.47$ & $7.36 \pm 0.02$ & \\
\hline End & $7.31 / 7.45$ & $7.36 \pm 0.02$ & \\
\hline \multicolumn{3}{|l|}{ Difference } & ${ }^{b} p$ \\
\hline Beginning-10th minute & $-0.08 / 0.06$ & $-0.01 \pm 0.02$ & $0.011^{*}$ \\
\hline Beginning-end & $-0.07 / 0.07$ & $0.00 \pm 0.02$ & 0.185 \\
\hline $10^{\text {th }}$ minute-end & $-0.03 / 0.03$ & $-0.003 \pm 0.013$ & 0.052 \\
\hline $\mathrm{PO}_{2}(\mathrm{mmHg})$ & $\begin{array}{l}\text { Minimum/ } \\
\text { Maximum }\end{array}$ & Mean \pm SD & ap \\
\hline Beginning & $56 / 200$ & $93.22 \pm 21.22$ & \multirow{3}{*}{$<0.001$ ** } \\
\hline $10^{\text {th }}$ minute & $53.9 / 138$ & $84.60 \pm 16.24$ & \\
\hline End & $62.7 / 201.7$ & $93.24 \pm 20.68$ & \\
\hline \multicolumn{3}{|l|}{ Difference } & $b_{p}$ \\
\hline Beginning- $10^{\text {th }}$ minute & $-128.6 / 39$ & $-8.63 \pm 20.86$ & $<0.001$ ** \\
\hline Beginning-end & $-43.2 / 71.6$ & $0.02 \pm 16.01$ & 0.991 \\
\hline $10^{\text {th }}$ minute-end & $-130 / 32.8$ & $-8.65 \pm 20.72$ & $<0.001$ ** \\
\hline $\mathrm{PaCO}_{2}(\mathrm{mmHg})$ & $\begin{array}{l}\text { Minimum/ } \\
\text { Maximum }\end{array}$ & Mean \pm SD & ap \\
\hline Beginning & $33 / 56.8$ & $41.34 \pm 3.88$ & \multirow{3}{*}{$0.001^{* *}$} \\
\hline $10^{\text {th }}$ minute & $34.3 / 58$ & $42.87 \pm 4.04$ & \\
\hline End & $34 / 56$ & $42.46 \pm 3.86$ & \\
\hline \multicolumn{3}{|l|}{ Difference } & $b_{p}$ \\
\hline Beginning-10th minute & $-8 / 15$ & $1.53 \pm 3.39$ & $<0.001$ ** \\
\hline Beginning-end & $-10.6 / 13$ & $1.12 \pm 3.70$ & $0.009 * *$ \\
\hline $10^{\text {th }}$ minute-end & $-8 / 9.20$ & $0.42 \pm 3.52$ & 0.298 \\
\hline $\mathrm{HCO}_{3}$ & $\begin{array}{l}\text { Minimum/ } \\
\text { Maximum }\end{array}$ & Mean \pm SD & ap \\
\hline Beginning & $19.5 / 28.8$ & $24.83 \pm 1.37$ & \multirow{3}{*}{0.174} \\
\hline $10^{\text {th }}$ minute & $19.9 / 28.0$ & $24.44 \pm 1.55$ & \\
\hline End & $19.7 / 27.0$ & $24.39 \pm 1.39$ & \\
\hline \multicolumn{3}{|l|}{ Difference } & ${ }^{b} p$ \\
\hline Beginning-10th minute & $-3.4 / 1.8$ & $-0.16 \pm 0.92$ & 0.120 \\
\hline Beginning-end & $-3.0 / 1.5$ & $-0.11 \pm 0.74$ & 0.174 \\
\hline $10^{\text {th }}$ minute-end & $-3.0 / 2.8$ & $0.05 \pm 0.87$ & 0.617 \\
\hline BE & $\begin{array}{l}\text { Minimum/ } \\
\text { Maximum }\end{array}$ & Mean \pm SD & $c_{p}$ \\
\hline Beginning & $-6 / 2$ & $\begin{array}{l}-0.78 \pm 1.40 \\
(-1.0)\end{array}$ & \multirow[t]{3}{*}{0.854} \\
\hline $10^{\text {th }}$ minute & $-5 / 2$ & $\begin{array}{l}-0.84 \pm 1.41 \\
(-1.0)\end{array}$ & \\
\hline End & $-5 / 2$ & $\begin{array}{l}-0.78 \pm 1.43 \\
(-1.0)\end{array}$ & \\
\hline \multicolumn{3}{|l|}{ Difference } & $d p$ \\
\hline Beginning-10th minute & $-2 / 2$ & $0.06 \pm 0.75$ & 0.431 \\
\hline Beginning-end & $-2 / 3$ & $0.00 \pm 0.83$ & 0.950 \\
\hline $10^{\text {th }}$ minute-end & $-2 / 2$ & $-0.06 \pm 0.80$ & 0.452 \\
\hline
\end{tabular}

\begin{tabular}{|c|c|c|c|}
\hline Blood $\mathrm{SPO}_{2}$ & $\begin{array}{l}\text { Minimum/ } \\
\text { Maximum }\end{array}$ & Mean \pm SD & ap \\
\hline Beginning & $90 / 99.8$ & $96.71 \pm 1.80$ & \multirow{3}{*}{$<0.001$ ** } \\
\hline $10^{\text {th }}$ minute & $84.5 / 99.4$ & $95.33 \pm 2.93$ & \\
\hline End & $92 / 99.2$ & $96.39 \pm 1.57$ & \\
\hline \multicolumn{3}{|l|}{ Difference } & $b_{p}$ \\
\hline Beginning-10th minute & $-11.3 / 7.6$ & $-1.38 \pm 3.33$ & $<0.001$ ** \\
\hline Beginning-end & $-7 / 7$ & $-0.32 \pm 2.28$ & 0.214 \\
\hline $10^{\text {th }}$ minute-end & $-14.1 / 4.5$ & $-1.06 \pm 3.09$ & $0.003 * *$ \\
\hline
\end{tabular}

\begin{tabular}{|c|c|c|c|}
\hline $\begin{array}{l}\mathrm{PaCO}_{2} \text { - End } \mathrm{CO}_{2} \\
\text { difference }\end{array}$ & $\begin{array}{l}\text { Minimum/ } \\
\text { Maximum }\end{array}$ & Mean \pm SD & $p$ \\
\hline Beginning & $-2.60 / 18.8$ & $5.22 \pm 4.26(5,10)$ & \multirow[t]{3}{*}{0.802} \\
\hline $10^{\text {th }}$ minute & $-4 / 16.8$ & $5.25 \pm 4.98(5,0)$ & \\
\hline End & $-5 / 18.1$ & $5.13 \pm 3.85(5,0)$ & \\
\hline
\end{tabular}

Table 6. Correlation between mean values of IPI and mean values of $\mathrm{EndCO}_{2}$. $\mathrm{SpO}_{2}$ and $\mathrm{PaCO}_{2}$

\begin{tabular}{|l|l|l|}
\hline \multirow{2}{*}{} & \multicolumn{2}{|l|}{ Mean IPI values } \\
\cline { 2 - 3 } & rho & p \\
\hline Mean $\mathrm{SpO}_{2}$ & 0.180 & 0.106 \\
\hline Mean end $\mathrm{CO}_{2}$ & 0.124 & 0.269 \\
\hline Mean $\mathrm{PaCO}_{2}$ & -0.092 & 0.412 \\
\hline IPI: Integrated Pulmonary Index & \multicolumn{2}{|l}{} \\
\hline
\end{tabular}

There have been different studies examining the efficiency of micro stream capnography conducted in different age groups and intubated and extubated patients $(10,17,18)$.

There are few studies in the literature investigating $\mathrm{ETCO}_{2}$ measurements with microstream during endoscopic procedures. These studies were mostly conducted on patients who underwent upper gastrointestinal endoscopy $(4,5,11)$.

In their study including 163 children undergoing 174 elective gastroinstestinal procedures, Lightdale et al. (11) randomized the patients to micro stream capnography and control groups. Endoscopy staff, who were blinded to additional capnography monitoring, reported poor ventilation in $3 \%$ of all procedures and no apnea, whereas capnography indicated alveolar hypoventilation and apnea during $56 \%$ and $24 \%$ of the procedures, respectively. The researchers concluded that sedation for endoscopy was safer with capnograph monitoring. 
Table 7. Correlation of IPI values with $\mathrm{SpO}_{2}$, End $\mathrm{CO}_{2}$ and $\mathrm{PaCO}_{2}$

\begin{tabular}{|c|c|c|c|c|c|c|}
\hline & \multicolumn{2}{|c|}{ IPI Beginning } & \multicolumn{2}{|c|}{ IPI $10^{\text {th }}$ minute } & \multicolumn{2}{|c|}{ IPI End } \\
\hline & rho & $p$ & rho & $p$ & rho & $p$ \\
\hline $\begin{array}{l}\mathrm{SpO}_{2} \\
\text { Beginning }\end{array}$ & -0.024 & 0.829 & 0.073 & 0.518 & -0.036 & 0.746 \\
\hline $\begin{array}{l}\mathrm{SpO}_{2} 10^{\text {th }} \\
\text { minute }\end{array}$ & -0.010 & 0.927 & 0.334 & $0.002^{* *}$ & 0.079 & 0.487 \\
\hline $\mathrm{SpO}_{2}$ End & 0.045 & 0.688 & 0.246 & $0.028^{*}$ & 0.179 & 0.107 \\
\hline $\begin{array}{l}\text { End } \mathrm{CO}_{2} \\
\text { Beginning }\end{array}$ & 0.187 & 0.093 & 0.219 & 0.051 & 0.136 & 0.222 \\
\hline $\begin{array}{l}\text { End } \mathrm{CO}_{2} \\
10^{\text {th }} \\
\text { minute }\end{array}$ & -0.071 & 0.531 & 0.166 & 0.142 & 0.178 & 0.115 \\
\hline $\begin{array}{l}\text { End } \mathrm{CO}_{2} \\
\text { End }\end{array}$ & -0.077 & 0.494 & 0.028 & 0.806 & 0.090 & 0.421 \\
\hline $\begin{array}{l}\mathrm{PaCO}_{2} \\
\text { Beginning }\end{array}$ & 0.073 & 0.512 & -0.079 & 0.485 & -0.168 & 0.131 \\
\hline $\begin{array}{l}\mathrm{PaCO}_{2} \\
10^{\text {th }} \\
\text { minute }\end{array}$ & -0.056 & 0.623 & -0.119 & 0.298 & -0.016 & 0.891 \\
\hline $\mathrm{PaCO}_{2}$ End & 0.266 & $0.016^{*}$ & -0.012 & 0.919 & -0.069 & 0.539 \\
\hline
\end{tabular}

Yarchi et al. (4) measured $\mathrm{ETCO}_{2}$ with the micro stream capnography in patients who received either general anesthesia or sedation for endoscopic procedures and underlined the importance of $\mathrm{ETCO}_{2}$ monitoring especially in upper gastrointestinal procedures under general anesthesia.

Qadeer et al. (5) monitored $\mathrm{ETCO}_{2}$ with the micro stream capnography in patients undergoing endoscopic retrograde cholangiopancreatograpy and endoscopic ultrasonography. They concluded that capnography monitoring improves patient safety during procedural sedation for endoscopy by reducing the frequency of respiratory depression.

Kugelman et al. (17) assessed correlation of capnographic $\mathrm{ETCO}_{2}$ measured with micro stream and arterial blood gas $\mathrm{PaCO}_{2}$ in premature infants ventilated with high frequency ventilation. The study results indicated correlation and feasibility of microstream capnography.

Casati et al. (10) conducted a similar study in adults, who underwent orthopedic or vascular surgery under general anesthesia, and compared $\mathrm{ETCO}_{2}$ and $\mathrm{PaCO}_{2}$ between intubated ventilated and spontaneously breathing nonintubated patients. The $\mathrm{ETCO}_{2}$ and $\mathrm{PaCO}_{2}$ values showed a perfect correlation in both groups as no significant difference was observed in $\mathrm{ETCO}_{2}$ and $\mathrm{PaCO}_{2}$ between intubated $(7.3 \pm 4 \mathrm{mmHg})$ and non-intubated $(6.5 \pm 4.8$ $\mathrm{mmHg}$ ) patients. Micro stream capnographical $\mathrm{ETCO}_{2}$ showed a closer correlation to $\mathrm{PaCO}_{2}$ in spontaneously breathing non-intubated patients. In our study this difference was $5.22 \pm 4.26 \mathrm{mmHg}$ at the beginning, $5.25 \pm 4.98 \mathrm{mmHg}$ at the $10^{\text {th }}$ minute and $5.13 \pm 3.85$ $\mathrm{mmHg}$ at the end of sedation in our spontaneously breathing non-intubated patients. These data were not statistically significantly different, which indicates safety of $\mathrm{ETCO}_{2}$ monitoring with micro stream capnography.

Singh et al. (19) reported microstream capnograph monitoring also to be easy to use during interhospital transport of intubated critically ill children, because the monitor had low weight, long battery life, audiovisual alarms, quantitative and graphic real-time detection of $\mathrm{ETCO}_{2}$ (20). Besides, micro stream capnography monitoring was also safe in confirming proper endotracheal tube positioning. Our study was realized outside the operating room. This is why easy transport of the monitor and also easy usage were very important.

A small number of studies reported that accurate $\mathrm{ETCO}_{2}$ measurements could not be done in non-intubated patients who received general anesthesia (21-22).

Cheng et al. (22) compared patients receiving general anesthesia with controlled ventilation and patients receiving total intravenous anesthesia with spontaneous breathing through the normal airway during gynecologic laparoscopic surgery and recorded $\mathrm{ETCO}_{2}$ and $\mathrm{PaCO}_{2}$ values at different time intervals and positions. $\mathrm{ETCO}_{2}$ was sampled through a suction catheter inserted into the nasopharynx. The results of this study showed that $\mathrm{ETCO}_{2}$ and $\mathrm{PaCO}_{2}$ values were correlated during the first 20 minutes after the change to the Trendelenburg position, but afterwards, $\mathrm{PaCO}_{2}$ monitoring was still necessary. This study indicated that patient's position during capnographic monitoring may be important. In our study, we had relatively precise correlation between the measurements. This may be a result of a lateral decubitis position given to all patients. However, ETCO 2 sampling and monitoring should also be considered. We used a nasal sampling line belonging to the microstream capnograph monitor, which may also be helpful to achieve precise measurements.

Bower et al. (23) evaluated sedation depth during endoscopic procedures by measuring BIS and Observer's Assessment of Alertness/Sedation which were correlated to each other. A BIS level near 82 was sufficient for sedation. BIS monitoring can inform the anesthesiologist about the patient's sedation status objectively. In our study, we evaluated the sedation depth using both the RSS and BIS. The mean RSS score was 4 and BIS was $60.7 \pm 6.44$. Our sedation depth was quite sufficient for colonoscopical examination and the colonoscopist was satisfied.

IPI was presented as a factor combining the best of all monitoring techniques to based on parameters of capnography and pulse oximetry. The use of IPI in monitoring 
patients under sedation was questioned in recent studies. In their study, Berkenstandt et al. (24) observed only a limited agreement between respiratory physiological parameters and IPI. Riphaus et al. (6) evaluated clinical value of IPI during sedation for interventional upper GIendoscopy and concluded that IPI monitoring does not add significant clinical benefit to standard monitoring. On the contrary, Garah et al. (25) in their study on 109 pediatric patients undergoing mainly upper endoscopy under sedation found that IPI had a high sensitivity in predicting apnea episodes and hypoxia events. In our study, IPI values were correlated with $\mathrm{ETCO}_{2}, \mathrm{SpO}_{2}$ and $\mathrm{PaCO}_{2}$ values.

In our study, desaturation was observed in three patients. These patients were treated with oxygen supplement. Micro stream capnography was useful in detection of hypoventilation in nine patients. We observed that an IPI of $<7$ in four of our patients correlated with $10^{\text {th }}$ minute $\mathrm{SpO}_{2}$ values. We believe that desaturation was rarely observed in our patients in comparison with hypoventilation because of short duration of sedation. In case of long duration of anesthesia outside the operating room, hypoventilation may occur more frequently. In such patients, the use of micro stream capnography may play an important role in preventing and decreasing hypoxic events. In our study, IPI monitoring did not add a clinical benefit to early recognition of hypoventilation.

\section{Conclusion}

In conclusion, even if IPI monitoring does not add a clinical benefit to early recognition of hypoventilation, we believe that non-invasive $\mathrm{ETCO}_{2}$ monitoring with micro stream capnography is useful for monitoring sedation and hypoventilation during colonoscopy procedures and it was found to be well correlated with $\mathrm{PaCO}_{2}$ values in arterial blood gas sampling. This study shows that non-invasive $\mathrm{ETCO}_{2}$ monitoring with micro stream capnography should be a part of routine monitoring for safe anesthetic practice outside the operating room.

\section{Acknowledgements}

The authors thank all the members of the endoscopy unit team for their support.

\section{Authorship Contributions}

Surgical and Medical Practices: S.O., H.S.T., C.T.I., P.S., L.K. Concept: S.O., H.Ş.T., C.T.I., P.S., L.K. Design: S.O., H.S.T., C.T.I., P.S., L.K. Data Collection or Processing: S.O., H.S.T., C.T.I., P.S., L.K. Analysis or Interpretation: S.O., H.S.T., C.T.I., P.S., L.K. Literature Search: S.O., H.S..T., C.T.I., P.S., L.K. Writing: S.O., H.S.T., C.T.I., P.S., L.K.

Conflict of Interest: No conflict of interest was declared by the authors.
Financial Disclosure: The authors declared that this study received no financial support.

\section{References}

1. Álvarez J, Cabadas R de la Matta M. Patient Safety Under Deep Sedation for Digestive Endoscopic Procedures. Rev Esp Enferm Dig 2017;109:137-43.

2. Leslie K, Allen ML, Hessian EC, et al. Safety of Sedation for Gastrointestinal Endoscopy in a Group of Universityaffiliated Hospitals: a Prospective Cohort Study. Br J Anaesth 2017;118:90-9.

3. Friedrich-Rust M, Welte $M$, Welte $C$, et al. Capnographic monitoring of propofol-based sedation during colonoscopy. Endoscopy 2014;46:236-44.

4. Yarchi D, Cohen A, Umansky T, et al. Assessment of endtidal carbon dioxide during pediatric and adult sedation for endoscopic procedures. Gastrointest Endosc 2009;69:87782.

5. Qadeer MA, Vargo JJ, Dumot JA, et al. Capnographic monitoring of respiratory activity improves safety of sedation for endoscopic cholangiopancreatography and ultrasonography. Gastroenterology 2009;136:1568-76.

6. Riphaus $A$, Wehrmann $T$, Kronshage $T$, et al. Clinical value of the Integrated Pulmonary Index® during sedation for interventional upper Gl-endoscopy: A randomized, prospective tri-center study. Dig Liver Dis 2017;49:45-9.

7. Cambra Lasaosa FJ, Pons Odena M. Pulse oximetry and capnography. An Pediatr (Barc) 2003;59:259-64.

8. Türk HŞ, Aydoğmuş $M$, Ünsal $O$, et al. Sedation-analgesia in elective colonoscopy: propofol-fentanyl versus propofolalfentanil. Rev Bras Anestesiol 2013;63:352-7.

9. Wren KR. Ventilation monitoring during monitored anesthesia care: a review. AANA J 1994;62:521-6.

10. Casati A, Gallioli G, Scandroglio M, et al. Accuracy of end-tidal carbon dioxide monitoring using the NBP-75 microstream capnometer. A study in intubated ventilated and spontaneously breathing nonintubated patients. Eur J Anaesthesiol 2000;17:622-6.

11. Lightdale JR, Goldmann DA, Feldman HA, et al. Microstream capnography improves patient monitoring during moderate sedation: a randomized, controlled trial. Pediatrics 2006;117:e1170-8.

12. Rowan CM, Speicher RH, Hedlund T, et al. Implementation of continuous capnography is associated with a decreased utilization of blood gases. J Clin Med Res 2015;7:71-5.

13. Whorwell PJ, Smith CL, Foster KJ. Arterial blood gas tensions during upper gastrointestinal endoscopy. Gut 1976;17:797800.

14. Fassoulaki A, Mihas A. Changes in arterial blood gases associated with gastrointestinal endoscopies. Acta Anaesthesiol Belg 1987;38:127-31. 
15. Darvas K, Tarjányi M, Molnár Z, et al. Sedation for ambulatory endoscopy. Acta Chir Hung 1999;38:143-6.

16. Dumonceau JM, Riphaus A, Schreiber $F_{1}$ et al. Nonanesthesiologist administration of propofol for gastrointestinal endoscopy: European Society of Gastrointestinal Endoscopy, European Society of Gastroenterology and Endoscopy Nurses and Associates Guideline-Updated June 2015. Endoscopy 2015;47:1175-89.

17. Kugelman A, Riskin A, Shoris I, et al. Continuous integrated distal capnography in infants ventilated with high frequency ventilation. Pediatr Pulmonol 2012;47:876-83.

18. Nik Hisamuddin NA, Rashidi A, Chew KS, et al. Correlations between capnographic waveforms and peak flow meter measurement in emergency department management of asthma. Int J Emerg Med 2009;2:83-9.

19. Singh S, Venkataraman ST, Saville A, et al. NPB-75: A portable quantitative microstream capnometer. Am J Emerg Med 2001;19:208-10.

20. Singh S, Allen WD Jr, Venkataraman ST, et al. Utility of a novel quantitative handheld microstream capnometer during transport of critically ill children. Am J Emerg Med 2006;24:302-7.

21. Delerme S, Freund $Y$, Renault R, et al. Concordance between capnography and capnia in adults admitted for acute dyspnea in an ED. Am J Emerg Med 2010;28:711-4.

22. Cheng KI, Tang CS, Tsai EM, et al. Correlation of arterial and end-tidal carbon dioxide in spontaneously breathing patients during ambulatory gynecologic laparoscopy. J Formos Med Assoc 1999; 98:814-9.

23. Bower AL, Ripepi A, Dilger J, et al. Bispectral index monitoring of sedation during endoscopy. Gastrointest Endosc 2000;52:192-6.

24. Berkenstadt $H$, Ben-Menachem E, Herman A, et al. An evaluation of the Integrated Pulmonary Index (IPI) for the detection of respiratory events in sedated patients undergoing colonoscopy. J Clin Monit Comput 2012;26:177-81.

25. Garah J, Adiv OE, Rosen I, et al. The value of Integrated Pulmonary Index (IPI) monitoring during endoscopies in children. J Clin Monit Comput 2015;29:773-8. 